\title{
Detrital Avalonian zircons in the Laurentian Southern Uplands Terrane, Scotland
}

\author{
E. R. Phillips ${ }^{1 *}$, J. A. Evans ${ }^{2}$, P. Stone ${ }^{1}$, M. S. A. Horstwood ${ }^{2}$, J. D. Floyd ${ }^{1}$, R. A. \\ Smith $^{1}$, M. C. Akhurst ${ }^{1}$ \& H. F. Barron ${ }^{1}$
}

1. British Geological Survey, Murchison House, West Mains Road, Edinburgh EH9

$$
\text { 3LA, UK. * e-mail: erp@bgs.ac.uk }
$$

2. NERC Isotope Geosciences Laboratory, Keyworth, Nottingham NG12 5GG, UK

\begin{abstract}
The Siluro-Ordovician Southern Uplands terrane occupies a key position in the Caledonian Orogen, yet its genesis is controversial. Marginal basin, back-arc and forearc tectonic regimes, operative at the Laurentian margin of the Iapetus Ocean, have all been invoked. Fresh andesitic detritus within turbidite sandstones has, until now, been assumed to provide evidence for an Ordovician, supra-subduction volcanic arc, a central feature of most models. However, high-precision TIMS U-Pb and laser ablation data for detrital zircons from the sandstone prove Neoproterozoic volcanism at $557 \pm 6 \mathrm{Ma}(2 \sigma)$ and $613 \pm 12 \mathrm{Ma}(2 \sigma)$. The complex crystallisation history recorded by the zircons shows assimilation of $1043 \pm 7 \mathrm{Ma}(2 \sigma)$, Grenvillian basement into the andesite magma. No zircons have been found which overlap the Caradoc depositional age of the host sedimentary rocks, so undermining all extant terrane models. The age profile of the detrital zircons is typical of Gondwana/Avalonia. This has important implications for the palaeogeography of the Iapetus Ocean during the Ordovician, since it requires the introduction of Avalonian detritus into a sedimentary basin marginal to Laurentia.
\end{abstract}

Keywords: Southern Uplands terrane, detrital zircons, geochronology, Avalonian arc volcanism 


\section{INTRODUCTION}

Within the Caledonian Orogen, the suspect Southern Uplands terrane lies between the Laurentian margin and the Iapetus Suture (the line of collision between Laurentia and Avalonia), and close to the triple junction between Laurentia, Baltica and Avalonia (Fig. 1). The terrane comprises a southwards-verging, imbricate thrust belt, incorporating Ordovician (in the north) and Silurian (in the south) turbidite facies strata, that developed as the Iapetus Ocean closed. A correct analysis of the tectonics involved would provide important control on the timing, duration and geometry of ocean closure, but there is currently no consensus. Competing interpretations for the thrust belt include: (1) forearc, oceanic trench deposits incorporated into a suprasubduction zone accretionary prism at the margin of Laurentia (Leggett et al., 1979); (2) a northern sector formed by the deformed fill of a back-arc basin, that developed southwards as a foreland fold and thrust belt following collision between Laurentia and Avalonia (Morris, 1987; Stone et al., 1987); (3) a northern sector initiated as a continental margin, extensional forearc basin formed at the Laurentian periphery (Armstrong et al., 1996) with foreland fold-and-thrust tectonics thereafter.

A crucial divergence of these models is their differing interpretation of Caradoc to Llandovery sandstones containing abundant fresh andesitic detritus. These were derived from the south (oceanward) whereas the majority quartzofeldspathic sandstones, with which the volcaniclastic varieties are interbedded, have a northern (continental) source. The andesitic material is remarkably fresh and relatively radiogenic, with $\varepsilon N d$ values for the volcaniclastic sandstones of about -2 to -4 (Stone and Evans, 1995). These features have consistently been taken to indicate erosion of the andesitic sediment from a contemporaneously active arc. An unambiguous acceptance of the palaeocurrent evidence, and hence of an oceanic arc to the south, is axiomatic to the back-arc model. Alternatively, within a forearc trench, meandering turbidity currents may give a spurious, southerly derivation for volcaniclastic sand that was actually sourced from a continental margin arc to the north. As a compromise, Kelling et al. (1987) invoked strike-slip tectonics to move an arc across the face of a trench.

Of the problems that still bedevil both the forearc and back-arc models, the lack of an identifiable volcanic source is the most acute. Furthermore, doubt was cast

upon depositionally contemporaneous volcanism by ${ }^{40} \mathrm{Ar}-{ }^{39} \mathrm{Ar}$ ages of $560 \pm 50$ and 530 \pm 10 Ma (i.e. late Neoproterozoic to earliest Cambrian) obtained from detrital 
hornblende (Kelley and Bluck, 1989). An accurate age for the volcanic detritus would go a long way towards resolving some of the outstanding interpretational problems. New high precision TIMS U-Pb and laser ablation ages are presented in this paper for a detrital zircon population from a Southern Uplands volcaniclastic sandstone. They show: (1) the fresh, andesitic detritus was indeed derived from an older Neoproterozoic arc; (2) the arc was founded upon Grenvillian basement; (3) the sedimentary provenance was probably Avalonian.

The dated zircons were extracted from pyroxenous sandstone of the Caradocian Portpatrick Formation that ranges up to $2000 \mathrm{~m}$ in thickness, spans the full $200 \mathrm{~km}$ strike length of the Southern Uplands terrane, and extends westwards into Ireland (Stone et al., 1987). In thin section, the detrital zircon grains show several morphologies: (1) small (30-100 $\mu \mathrm{m})$ faceted crystals are most abundant; they occur as both isolated grains and inclusions within plagioclase or hornblende, both of which occur as phenocrysts within andesitic clasts; (2) larger (100-150 $\mu \mathrm{m}$, rarely up to 250 $\mu \mathrm{m})$, longer and elongate faceted crystals contained within detrital plagioclase grains; (3) large (ca. $250 \mu \mathrm{m}$ ) rounded crystals included within quartzofeldspathic metamorphic lithic clasts; and (4) rare large, rounded, isolated, abraded grains which may be polycyclic in origin. Morphologies 1 and 2 were taken as arising from the andesitic volcanism and are those for which the data is presented in this paper.

\section{DATING OF DETRITAL ZIRCONS}

The detrital zircons were analysed on a VG354 mass spectrometer at the NERC Isotope Geosciences Laboratory following procedures described by Noble et al. (1993). Results were calculated and plotted following Ludwig (1993, 1994). Dating was undertaken in two stages. Firstly, laser ablation of 30 zircon grains, representing the main morphological types, was used to assess their age distribution (Fig. 2). This showed that the ${ }^{206} \mathrm{~Pb} /{ }^{238} \mathrm{U}$ ages ranged between $583 \pm 38 \mathrm{Ma}(2 \sigma)$ and $1269 \pm 58 \mathrm{Ma}(2 \sigma)$, with the majority of the data falling between 800 and $1050 \mathrm{Ma}(\mathrm{n}=$ 18) (Fig. 2). No grains were found with ages that overlapped the Caradoc depositional age of the sedimentary rocks (about 450-445 Ma), nor were there any Palaeoproterozoic or older grains.

Information from the laser study, coupled with zircon morphology, was then used to select representative zircons for high-precision TIMS analysis. Eighteen single 
grains and three multigrain fractions were selected on the basis that they showed minimal sedimentary erosion and contained no visible inclusions. Consequently, only faceted zircons, representing morphological types 1 and 2, were analysed in an attempt to constrain the age of the volcanic detritus which characterises the Portpatrick Formation sandstones. No examples of the large polycyclic grains (morphology type 4) where recognised within mineral separate. The single grains fall along a discordia (Fig. 2), with the multigrain fractions lying on a discordant trend, possibly reflecting a mixed age population despite the grains having been selected for similarity in size, shape, and crystal clarity. The upper intercept is given by the concordant age from three larger faceted grains (type 2) as 1043 \pm 7 Ma. The lower intercept is defined by two points that give a concordant age of $557 \pm 6$ Ma and was obtained from small (type 1) zircons. These small zircons lack an obvious core and are interpreted as representing a single phase of magmatic growth. The occurrence of these small zircon grains within plagioclase and, in some cases, hornblende is considered to provide an age for andesitic magmatism of ca. $557 \mathrm{Ma}$. A single small zircon grain also plotted on a concordia, yielding an age of $613 \pm 12 \mathrm{Ma}$. The rest of the data obtained for the larger faceted (type 2) crystals range between the two endmembers, mimicking the behaviour of the multigrain fractions. The 557 to $1043 \mathrm{Ma}$ array overlaps the range of ${ }^{206} \mathrm{~Pb} /{ }^{238} \mathrm{U}$ ages obtained through laser ablation (583 to $1269 \mathrm{Ma})$.

Back scatter and cathode-luminescence, SEM images reveal that the large faceted detrital zircons (type 2) do not have a simple one-stage crystallisation history, but are internally complex, with an older, broken, low-uranium core (zoned) enclosed within a younger, faceted and magmatically zoned rim (Fig. 3). The TIMS ${ }^{206} \mathrm{~Pb} /{ }^{238} \mathrm{U}$ ages and laser analysis data can, therefore, be interpreted as reflecting a detrital zircon population with a common history of basement inheritance with later overgrowths. The upper intercept age of ca. $1043 \mathrm{Ma}$ is regarded as dating the first phase of zircon growth. These Grenvillian grains were then incorporated into a rock that precipitated new zircon, as well as overgrowths upon older grains, when it crystallised during andesitic magmatism at about 557 Ma.

\section{THE AGE OF THE CRYPTIC VOLCANIC PROVENANCE}


Geotectonic models for the Southern Uplands have all regarded the fresh and abundant, detrital andesitic material as recording active arc volcanicity contemporaneous with Caradoc to Llandovery sedimentation (Styles et al., 1995). Against this background, dating of the andesitic material has given surprising results.

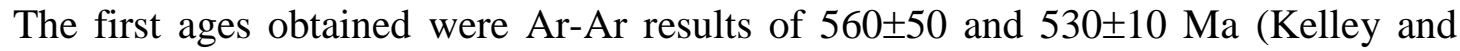
Bluck, 1989). The high precision U-Pb zircon and laser ablation ages presented here more closely define andesitic magmatism as dominated by an event at about $557 \mathrm{Ma}$ with an earlier episode at about $613 \mathrm{Ma}$; both occurred towards the end of the Neoproterozoic. The older Grenville aged zircons (ca. $1047 \mathrm{Ma}$ ) assimilated into this andesitic magma probably represent the age of the continental crust upon which the volcanic arc was founded. Despite the remarkable freshness of the volcanic detritus it is no longer tenable to assume penecontemporaneous eruption and sedimentation. Instead, exhumation and erosion of the Neoproterozoic volcanic rocks must be invoked, with equally rapid burial of the resulting sediment.

In the Midland Valley terrane, to the north of the Southern Uplands (Fig. 1), Late Ordovician conglomerates contain granite boulders dated (Rb-Sr) at about 560 and 470 Ma (Longman et al., 1979). Whilst the former are approximately matched by the Southern Uplands zircon dates, the latter ages are notable for their absence in the zircon suite. However, conglomerates from the Southern Uplands terrane do contain granite clasts of about 470 Ma (Elders, 1987), detrital micas from sandstones have ${ }^{40} \mathrm{Ar}^{-39} \mathrm{Ar}$ cooling ages in the range $<458$ to $>502 \mathrm{Ma}$. (Kelley and Bluck, 1989), and a Sm-Nd age of $468.7 \pm 1.5$ Ma has been obtained from detrital garnet (Oliver et al., 2000). Detrital zircons from a Caradocian quartzofeldspathic sandstone (Kirkcolm Formation) dated by Halliday et al. (1984) lie on a discordia with a lower intercept at $<<500 \mathrm{Ma}$, and do not reflect the $557 \mathrm{Ma}$ event. These zircon ages, the $470 \mathrm{Ma}$ ages for granites, and the 469 Ma garnet age, were all obtained from strata that had a provenance to the north, in the Laurentian continent. The southerly derived Portpatrick Formation records the presence of an unrelated source terrane that did not experience Ordovician magmatism. The ubiquitous 458-502 Ma detrital mica ages are possible minima arising from resetting caused by argon loss during burial, structural imbrication and low-grade metamorphism. They do not record any Grenville influence and extend to younger ages than that of deposition.

\section{AN AVALONIAN SOURCE FOR THE DETRITAL ZIRCONS?}


Elsewhere in the Caledonian Orogen, the age ranges of detrital zircon populations have been used to establish their likely provenance. Van Staal et al. (1996) concluded that the range (540-550, 600-800, 1000-1500 Ma) obtained from the Gander Zone of Newfoundland eliminated Laurentia as a possible basement, and instead identified Gondwana. McNicoll et al. (2001), discussing the OrdovicianSilurian accretionary history of the northern Appalachians, found an abundance of Cambro-Ordovician zircons in Laurentia-derived sedimentary rocks and argued that the absence of zircons in the range 680 to 530 Ma ruled out an Avalonian input. The detrital zircon assemblage within the Portpatrick Formation (557, 613 and $1047 \mathrm{Ma}$ ) hence seems likely to have had an Avalonian rather than a Laurentian provenance.

Intra-Iapetus arcs have been identified palaeomagnetically by Mac Niocaill et al. (1997) and a specifically Avalonian arc terrane has been proposed by Van Staal et al. (1998) as a source for the Southern Uplands detritus. However, these examples are Ordovician and incompatible with the new zircon ages. Instead, a source for the Neoproterozoic andesitic debris might be sought in the Avalonian hinterland where magmatism of the appropriate age is widely recorded: for example, in Newfoundland (590 Ma to early Cambrian; O’Brien et al., 1996) or in New Brunswick (620 and 560550 Ma; Barr and White, 1996). The closest match with the Portpatrick Formation ages (about 613 and $557 \mathrm{Ma}$ ) is actually seen in Britain where Avalonian magmatism occurred in two phases: 620 to 600 Ma and 570 to 550 Ma (Gibbons and Horak, 1996; Compston et al., 2002). A broadly similar pattern has been established for Ganderia, the Newfoundland Gander Zone basement, by van Staal et al., (1996). Van Staal et al., (1998) consider that it is this Ganderian basement, which is mainly composed of early Cambrian (550-540 Ma), Neoproterozoic (0.85-0.6 Ga), Mesoproterozoic (1.6-1.0 Ga) and Archean (ca. 2.7 Ga) rocks, that continues beneath northern England and Wales rather than Avalonia s.s. Despite the close similarity of the Southern Uplands zircon ages with those of Avalonia or Ganderia there is one serious obstacle to direct association. In northern England, a major phase of Caradoc volcanism occurred at around 450 Ma (Noble et al., 1993; Hughes et al., 1996) and would have been expected to contribute to sediment eroded from that region.

A possible solution to this provenance dilemma is provided by the crustal magnetic variation across the Iapetus Suture Zone. This reveals the presence of a magnetic basement block beneath the southern part of the Southern Uplands (Kimbell and Stone, 1995) bordered to the south by the northward dipping Iapetus Suture, and 
to the north by a deep structure coincident with a major shear zone at the surface. Kimbell and Stone (1995) noted that the geophysical characteristics of this magnetic unit are similar to those of the continent to the south, across the suture, and suggested that it originated as a rifted fragment of the Avalonian margin that became trapped on the "wrong" side of the Iapetus Suture. In this situation, if rifting preceded the Caradocian magmatism of northern England, then the isolated continental fragment could have preserved the Neoproterozoic age profile characteristic of Avalonia. If the basement to northern England is regarded as a fragment of Ganderia rather than Avalonia it does not affect the main argument, that an unrelated fragment of basement provided a southerly derived sediment source within the mainly Laurentian-derived Southern Uplands terrane.

Both Kimbell and Stone (1995) and Armstrong and Owen (2001) proposed that the magnetic basement beneath the southern part of the Southern Uplands represented the "lost” Avalonian (but perhaps Ganderian) arc that shed fresh andesitic detritus into the Portpatrick Formation. The latter authors named the lost arc Novantia. If these regional interpretations are broadly correct, the results presented here show Novantia to be exclusively Proterozoic, without the early Palaeozoic volcanic component previously assumed. We suggest that its erosion resulted in the interdigitation of Avalonian/Ganderian-derived sediment with the mainly Laurentianderived sediment of the Southern Uplands terrane.

\section{CONCLUSIONS}

High-precision TIMS U-Pb dating and laser ablation analysis of detrital zircons from volcaniclastic sandstone within the Southern Uplands terrane prove Neoproterozoic calc-alkaline magmatism at about 613 and $557 \mathrm{Ma}$, rather than during the late Ordovician as previously assumed. The complex crystallisation history recorded by the zircons is one of assimilation of Grenvillian (ca. $1043 \mathrm{Ma}$ ) basement into this andesite magma. No zircons have ages anywhere near the ca. $450 \mathrm{Ma}$ deposition of the host Caradoc turbidite sandstones. Consequently, despite the remarkable freshness of the detritus, penecontemporaneous eruption and sedimentation can no longer be assumed in support of either a back-arc or forearc model for the terrane. The age range provided by the zircon population suggests an Avalonian or possibly Ganderian provenance for the volcanic detritus. The presence of an arc terrane unrelated to Laurentia, but within sedimentation range of the 
Laurentian margin during the Ordovician, suggests a more complicated history for the Iapetus Ocean than is commonly supposed. In particular it emphasises the early date at which terranes rifted from Gondwana (s.l.) and migrated northwards across the ocean.

\section{ACKNOWLEDGEMENTS}

Thanks to Elizabeth Pickett for comments on an earlier version of this paper, Adrian Wood for zircon separation, Neil Boulton and Heather Billin for assistance with mass spectrometry, and Grenville Turner for SEM expertise. The referees Cees van Staal and Peter Cawood, are both acknowledge for their constructive reviews. This paper is published by permission of the Executive Director, British Geological Survey (NERC). NIGL publication number 561.

\section{REFERENCES}

Armstrong, H.A. and Owen, A.W. 2001. Tectonic evolution of the paratectonic Caledonides of Northern Britain. Journal of the Geological Society, London, 158, 475-486.

Armstrong, H.A., Owen, A.W., Scrutton, C.T., Clarkson, E.N.K. and Taylor, C.M. 1996. Evolution of the Northern Belt, Southern Uplands: implications for the Southern Uplands controversy. Journal of the Geological Society, London. 153, 197-205.

Barr, S.M. and White, C.E. 1996. Contrasts in late Precambrian-early Palaeozoic tectonothermal history between Avalon composite terrane sensu stricto and other possible peri-Gondwanan terranes in southern New Brunswick and Cape Breton Island, Canada. In Nance, R.D. \& Thompson, M.D. (eds) Avalonian and Related Peri-Gondwanan Terranes of the Circum-North Atlantic. Geological Society of America Special Paper 304. Boulder, Colorado.

Bluck, B.J., Gibbons, W. and Ingham, J.K. 1992. Terranes. In Cope, J.C.W., Ingham, J.K. and Rawson, P.F. (eds) Atlas of Palaeogeography and lithofacies. Geological Society of London Memoir, No. 13, 1-4.

Compston, W., Wright, A.E. and Toghill, P. 2002. Dating the Late Precambrian volcanicity of England and Wales. Journal of the Geological Society, London. 159, 323-339. 
Elders, C.F. 1987. The provenance of granite boulders in conglomerates of the Northern and Central Belts of the southern Uplands of Scotland. Journal of the Geological Society, London. 144, 853-863.

Foster, G., Gibson, D., Parrish, R., Horstwood, M., Fraser, J. and Tindle, A. 2002. Textural, Chemical and Isotopic insights into the nature and behaviour of metamorphic monazite. Chemical Geology, 191, 183-207.

Gibbons, W. and Horak, J.M. 1996. The evolution of the Neoproterozoic Avalonian subduction system: Evidence from the British Isles. In Nance, R.D. \& Thompson, M.D. eds. Avalonian and Related Peri-Gondwanan Terranes of the Circum-North Atlantic. Geological Society of America Special Paper 304. Boulder, Colorado.

Halliday, A.N., Aftalion, M., Upton, B.G.J., Aspen, P. and Jocelyn, J. 1984. U-Pb isotopic ages from a granulite-facies xenolith from Parten Craig in the Midland valley of Scotland. Transactions of the Royal Society of Edinburgh: Earth Sciences. 75, 71-74.

Hughes, R.A., Evans, J.A., Noble, S.R. and Rundle, C.C. 1996. U-Pb chronology of the Ennerdale and Eskdale intrusions supports sub-volcanic relationship with the Borrowdale Volcanic Group (Ordovician, English Lake District), Journal of the Geological Society, London. 153, 33-38.

Kelley, S. and Bluck, B.J. 1989. Detrital mica ages from the Southern Uplands using Ar-Ar laser probe. Journal of the Geological Society, London. 146, 401-403.

Kelling, G., Davies, P. and Holroyd, J. 1987. Style, scale and significance of sand bodies in the Northern and Central Belts, southwest Southern Uplands. Journal of the Geological Society, London. 144, 787-805.

Kimbell, G.S. and Stone, P. 1995. Crustal magnetization variations across the Iapetus Suture Zone. Geological Magazine. 132, 599-609.

Leggett J.K., McKerrow, W.S. and Eales, M.H. 1979. The Southern Uplands of Scotland; a Lower Palaeozoic accretionary prism. Journal of the Geological Society, London. 136, 755-770.

Longman, C.D., Bluck, B.J. and van Breeman, O. 1979. Ordovician conglomerates and the evolution of the Midland Valley. Nature, 280, 578-581.

Ludwig, K.R. 1993 PBDAT. A computer program for processing Pb-U-Th isotope data. version 1.24, U.S. Geological Survey Open-file Report 88-542. 
Ludwig, K.R. 1994. ISOPLOT: A plotting and regression program for radiogenicisotope data, version 2.75. U.S. Geological Survey Open-file Report, 91-445.

Mac Niocaill, C., van der Pluijm, B.A. and Van der Voo, R. 1997. Ordovician palaeogeography and the evolution of the Iapetus Ocean. Geology, 25, 159162.

McNicoll, V.J., Van Staal, C.R. and Waldron, J.W.F. 2001. Accretionary history of the northern Appalachians: SHRIMP study of Ordovician syntectonic sediments in the Canadian Appalachians. Programme with abstracts 26. Geological Association of Canada, St. John’s 2001. p. 100.

Morris, J.H. 1987. The Northern Belt of the Longford-Down, Ireland and Southern Uplands, Scotland: an Ordovician back-arc basin. Journal of the Geological Society, London. 144, 773-786.

Noble, S.R., Tucker, R.D. and Pharaoh, T.C. 1993. Lower Palaeozoic and Precambrian igneous rocks from eastern England and their bearing on Ordovician closure of the Tornquist Sea: constraints from U-Pb and $\mathrm{Nd}$ isotopes. Geological Magazine. 130, 835-46.

O’Brien, S.J., O’Brien, B.H., Dunning, G.R. and Tucker, R.D. 1996. Later Neoproterozoic Avalonian and related peri-Gondwanan rocks of the Newfoundland Appalachians. In Nance, R.D. and Thompson, M.D. (eds) Avalonian and Related Peri-Gondwanan Terranes of the Circum-North Atlantic. Geological Society of America Special Paper 304. Boulder, Colorado.

Oliver, G.J.H., Chen, F., Buchwaldt, R. and Hegner, E. 2000. Fast tectonometamorphism and exhumation in the type area of the Barrovian and Buchan zones. Geology, 28, 459-462.

Stone, P., Floyd, J.D., Barnes, R.P. and Lintern, B.C. 1987. A sequential back-arc and foreland basin thrust duplex model for the Southern Uplands of Scotland. Journal of the Geological Society, London. 144, 753-764.

Stone, P. and Evans, J.A. 1995. Nd-isotope study of provenance patterns across the Iapetus Suture. Geological Magazine. 132, 571-580.

Styles, M.T., Perez-Alverez, M. and Floyd, J.D. 1995. Pyroxenous greywackes in the Southern Uplands of Scotland and their petrotectonic implications. Geological Magazine. 132, 539-547.

Van Staal, C.R., Sullivan, R.W. and Whalen, J.B. 1996. Provenance and tectonic history of the Gander Zone in the Caledonian/Appalachian orogen: Implications for the 
origin and assembly of Avalon. In Nance, R.D. \& Thompson, M.D. (eds) Avalonian and Related Peri-Gondwanan Terranes of the Circum-North Atlantic. Geological Society of America Special Paper 304. Boulder, Colorado.

Van Staal, C.R., Dewey, J.F., Mac Niocaill, C. and McKerrow, W. S. 1998. The Cambrian - Silurian tectonic evolution of the northern Appalachians and British Caledonides: history of a complex, west and southwest Pacific-type segment of Iapetus. In Blundell, D.J. and Scott, A.C. (eds) Lyell: the past is the key to the present. Geological Society, London, Special Publications, 143, 199-242.

\section{Figure captions}

Fig. 1. Depositional setting of the Southern Uplands terrane within a Caradoc palaeogeographical reconstruction of the Iapetus Ocean (after Van Staal et al., 1998), and the position of the terrane within the British Caledonides (terrane nomenclature after Bluck et al., 1992).

Fig. 2. U-Pb concordia diagram for detrital zircons from the Portpatrick Formation. Single grains have grey fill and multigrain fractions have black fill. Error ellipses are plotted at the $\pm 2 \sigma$ level. The position of the discordia line was calculated from all the points. The lower and upper intercepts were determined by concordant ages on the three highest and two lowest points. Inset is a histogram of ${ }^{206} \mathrm{~Pb} /{ }^{238} \mathrm{U}$ ages determined by laser ablation on single zircon grains.

Fig. 3. Cathode-luminescence SEM images of: (a) a zircon grain (morphological type 2) composed of an older broken core enclosed within a later magmatically zoned rim with very sharp terminations and essentially no sedimentary erosion damage; (b) the broken end of a zoned, low-uranium zircon completely enclosed by new, magmatically zoned zircon (morphological type 2). 